\title{
PROBLEMS OF MASS BALANCE STUDIES
}

\author{
A symposium held in Cambridge, England, 5-7 January i 962, to celebrate \\ the twenty-fifth anniversary of the founding of the Society that is now the \\ Glaciological Society.
}

The Society, which was founded as the Association for the Study of Snow and Ice, and which, after the Second World War was renamed the British Glaciological Society, held its twenty-fifth anniversary celebrations in Cambridge, England from 5 to 7 January i 962 . These included an Extraordinary General Meeting at which a new Constitution for the Society was adopted and the name of the Society was changed to The Glaciological Society, a change which recognizes that, although our headquarters are at Cambridge, England, our membership and interests are world-wide. There was also an Anniversary Banquet at which the Lord Bishop of Norwich, the Rt. Rev. Dr. W. L. S. Fleming, proposed the toast of the Society to which our President, Mr. Gerald Seligman, replied, and a symposium on the problems of mass balance studies.

In this report of the symposium, several of the papers are printed in full and summaries are given of the others, together with an abbreviated report of the discussions that took place after each paper.

The programme of the symposium was as follows:

First session, 6 January ig62, io a.m. to 12.30 p.m.

Dr. M. F. Meier. Proposed definitions for glacier mass budget terms.

Dr. J. F. Nye. Implications of mass balance studies.

Professor H. C. Hoinkes. Mass balance studies on the Hintereisferner, Ötztal Alps, r 952-196r .

Dr. V. Schytt. Mass balance studies in Kebnekajse.

Second session, 6 January $1962,2.30$ p.m. to $5 \cdot 30$ p.m.

Mr. G. R. Elliston. Seasonal changes of speed in temperate valley glaciers.

Mr. E. R. LaChapelle. Assessing glacier mass budgets by reconnaissance aerial photography.

Dr. H. Lister. Mass balance studies on the Ellesmere Ice Shelf.

Dr. F. Nusser. Hydrological investigations into the problem of the mass balance of the Kangerdlugssuaq Gletscher.

Third session, 7 January i $962,2.30$ p.m. to 5.30 p.m.

Dr. F. Müller. Zonation in the accumulation area of the glaciers of Axel Heiberg Island, N.W.T., Canada.

Mr. J. T. Hollin. Some problems of the Antarctic mass budget.

Dr. C. R. Bentley. Surface slopes and ice thickness in West Antarctica. 